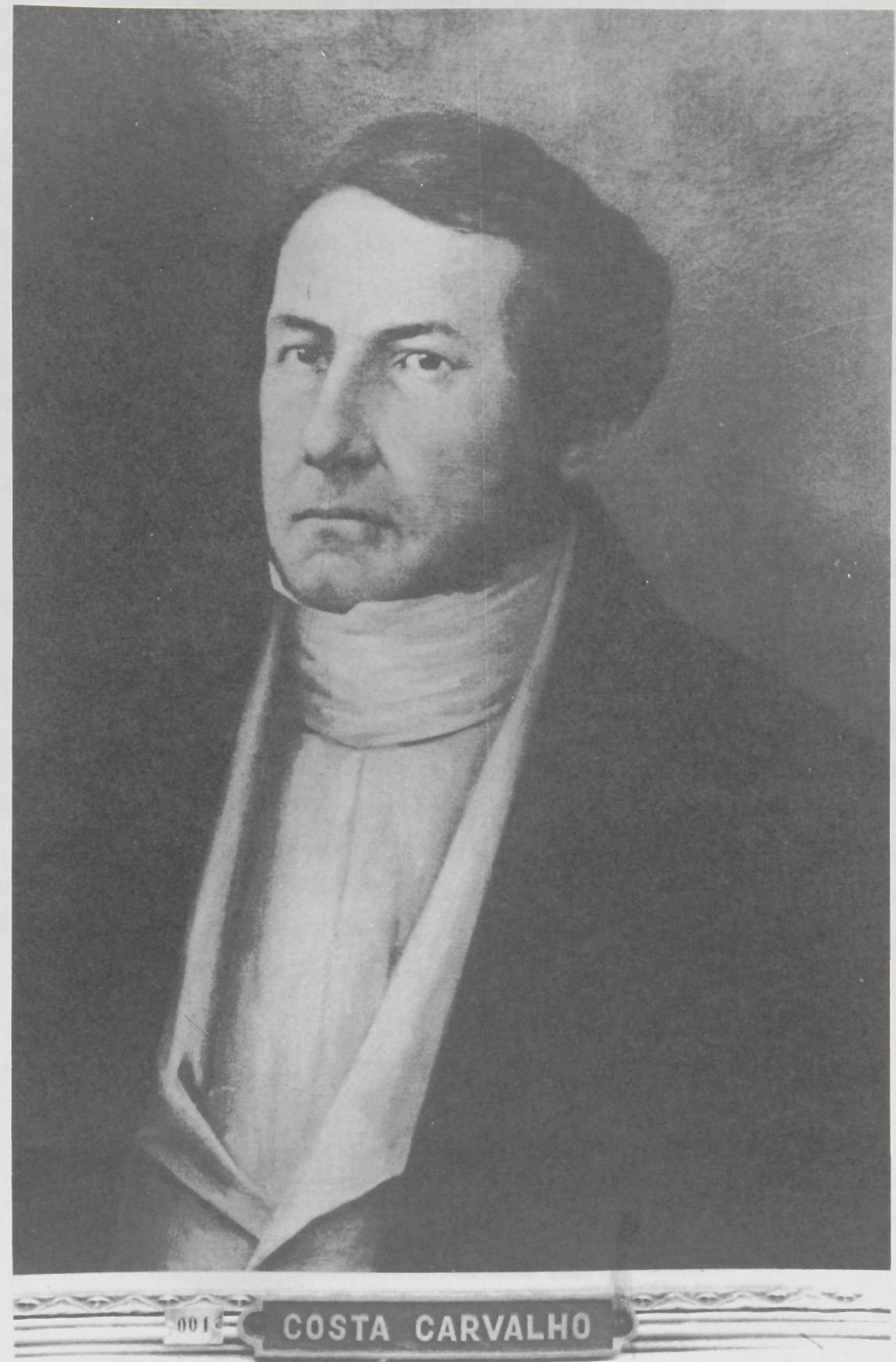





\section{Conselheiro Dr. JOSÉ DA COSTA CARVALHO \\ (Marquês de Monte Alegre)}

(1835-1836)

Filho legítimo do patrão-mor da barra da cidade de S. Salvador da Bahia, José da Costa Carvalho, e de D. Ignez Maria da Piedade, naquela cidade nasceu. Formou-se em leis na Universidade de Coimbra, em 1819. Voltando ao Brasil tornou-se juiz-de-fora da cidade de São Paulo, da qual foi ouvidor, de 1821 a 1822.

Constituiu familia em São Paulo, contraindo casamento com D. Genebra de Barros Leite, de importante e conceituada familia paulistana. Encabeçou o partido liberal, sendo companheiro de Feijó, Paula e Souza, Evaristo da Veiga, Bernardo de Vasconcellos e Honorio Hermeto Carneiro Leão.

\section{Fundou $O$ Farol Paulistano.}

Tomou parte na Constituinte e na Assembléia Legislativa, como deputado, na primeira, segunda e quarta legislaturas.

Com a abdicação de D. Pedro I, fez parte da Regência Permanente.

Por decreto de 5 de novembro de 1835 , foi nomeado diretor do Curso Jurídico de São Paulo. Tomou posse em 5 de dezembro e exonerou-se por decreto de 24 de junho de 1836 , servindo apenas seis meses e alguns dias.

Foi agraciado com o título de Barão de Monte Alegre, em 1841; com a carta de Conselheiro de Estado, em 1842; com o título de Visconde, em 1843; com o de Marquês, em 1854.

Organizou os gabinetes de 1848 e de 1852. 